\title{
Model of Skills Development at the Operational Level Applied to the Steel Industry
}

\author{
Ulysses Martins Moreira Filho and Pedro Luiz de Oliveira Costa Neto \\ Paulista University-UNIP, Graduate Program in Production Engineering \\ Rua Dr. Bacelar, 1212, 04026-002-São Paulo, Brazil
}

\begin{abstract}
The steel sector was one of the pioneers to join the Movement for Quality in Brazil in late 1980, because a significant portion of its revenues came from exports. The steel industry needs massive investment to upgrade its technology, which requires a high level of training of their operators. They must form a human capital capable of producing a laminate to win the preference of its customers. Based on four models of knowledge management: the SECI model, CYNEFIN model, the FIVE DISCIPLINES model and the SEVEN DIMENSIONS model, supported by the Knowledge Management Principles established by Davenport and Prusak, combined with the Criteria for Management Excellence, was developed a Competency Development Model. To validate this model has been carried out a field research in the governance representative of the national steel industry, with the aim to ensure safety in production operations and contribute positively to the manufacture with quality, reliability and competitiveness.
\end{abstract}

Keywords: Excellence in management, quality in operation, knowledge management.

\section{$1 \quad$ Introduction}

In 1984 Brazil was living a very complicated economic situation due to a strong inflationary process. The model focused on protectionism of domestic industry, allied to an obsolete technological park. This and the effect of globalization forced the Ministry of Industry and Trade to adopt a new attitude to face this reality.

So, the Industrial Technology Department of the Ministry has launched the PADCT - Support Program for Scientific and Technological Development, financed by the Brazilian Government and the World Bank, with the goal of bringing to the Brazilian entrepreneur, clearly and objectively, concepts and methodologies for implementation of "Total Quality" management systems which brought to the various companies in the world, in particular at Japan, gains in productivity, quality and competitiveness.

The Total Quality Management model in the Japanese style gives priority to the PDCA (Plan - Do - Check - Act) cycle management and the use of troubleshooting methods. 
The steel, petrochemical and mining sectors were pioneers in joining this movement, because a significant portion of their revenue comes from export. In the particular case of the steel industry, this model of quality management had a strong echo, due to the influence of the Japanese steel industry, present in a direct or indirect equity participation in this sector in the country.

The advance of scientific and technical knowledge and its dissemination in the productive process significantly changed the way of working, as well as the position of productive agents of the international market. Specificated production of quality with low cost, better capacity and quick innovation as key-factor of success put aside mass production. Holders of technical-scientific knowledge networks assume a privileged position in the world economic scenario [1].

Professional certification is also expanding in the national context, becoming present in a series of forums involving the Ministry of Labour and Employment, the International Labour Organization and the Ministry of Education, while the demand for professional certification of firms grows, as quality assurance strategy and competitiveness in a globalised market. This new reality was being experienced by Brazil.

In this process, the professional qualification in the new contemporary scenario arises as an important element in the composition of the factors influencing the competitiveness of countries, organizations and professionals.

A "new society" of knowledge arises, in which the human being is seen as an asset within organizations, with its own style, individuality and freedom of thought. The human capital is considered one of the main sources of innovation and organizational renewal. It is strengthened the creation of knowledge through activities in the knowledge construction process, generating shared solutions of problems, testing, implementation and integration of new methodologies and tools.

One of the main solutions adopted by Brazilian steel industry to overcome these new challenges posed by the market was the structuring of a standardization system of knowledge, through the certification process. The certification of competence based on the knowledge of the steel industry, established in technical standards or described in guidance manuals, ensures safety in the productive operations and contributes positively to the manufacture of quality products, reliability and competitiveness..

\section{Objective}

The objective of this paper it to present a model for developing skills for operators applied to the steel industry to strengthen its human capital, from the standardization of knowledge, to improve the quality required for excellence in control the production process.

\section{Methodology}

It were performed a multiple case study in steel mills ArcelorMittal, Gerdau, Usiminas, Votorantim and the Brazilian Association of Mining, Metallurgy and Materials, with application of an interview with the representative governance of the 
Brazilian steel industry, supported by a questionnaire with fourteen questions divided into three groups: perception of labor offered by the market (questions 1-3), specific knowledge to analyze and solve unforeseen problems (questions 5-11) and ability to achieve professional results (questions 12-14). For this analysis was elaborated a correlation matrix among the indicators of each issue to determine the degree of consistency in relation to the theoretical support.

\section{Theoretical Background}

This study focuses on the development of skills of people who operate equipment for mining and metallurgical industries. To explain the relationship of the problem with the hypothesis, it was drafted a model of competence development, which presents a systemic vision of the three strands that converge to the management of excellence: the information system, the knowledge system and independent data.

The organization information system is the basis for decision-making, structured in the form of management reports, according to the sixth principle of quality "factual approach to decision-making"[2].

The knowledge system is important as far as we nowadays recognize knowledge as one of the more important assets at the organization.

The independent data system is the measurement system of an organization's performance. The structured and systematic measurement enables organizations to monitor their performance and thus quickly make changes on the basis of relevant and reliable information as changes occur in the market [3].

The three systems converge for the management of an organization and excellence permeates the crux of the problem under consideration, which is the competence of persons as the centre of a triangle, whose vertices are the tacit or explicit knowledge [4], the standardization of repetitive tasks [5] and the quality of products offered to consumers [5]; [6]; [7].

In face of a globalized and turbulent scenario, the management model of an organization can be one of the factors for the explanation of the quality of its results and how is done the interrelationship among internal processes.

The construction and strengthening of skills leads to "education and training", because organizations learn through individuals [6]; [7]; [8]; [9].

People need to want actually learn, want growth and be open to innovations. To do so, paradigms should be broken in such a way as to change your mental model of behavior [10]. This leads to standardization of all knowledge acquired throughout life for people who operate the production process, strengthening the human capital and, consequently, its competence.

These skills must be recognized by a third party institution approved by INMETRO - National Institute of Metrology, Standardization and Industrial Quality, the Brazilian responsible institution. By means of a written examination, the operator must demonstrate that dominates the knowledge requirements established in Brazilian technical standards, contributing positively to the production of quality products required by the consumer, within the relevant time limits, i.e., focusing on operational 
effectiveness, waste control, producing operational safety and its institutional commitment. Every four years, professionals must be reevaluated by the criteria established in the referred qualification standards.

In conclusion, we can say that a management model is the body of knowledge in an organization and to achieve the business autossustainability is essential to stimulate organizational learning, together with the development of specific skills, being able to operate a system that will win the customer's preference.

\section{$5 \quad$ Skills Development Model}

This model has been structured on the basis of the seven principles of knowledge management established by Davenport and Prusak [11], on the model of knowledge management conceived by Nonaka and Takeuchi [4], the Cynefin model proposed by Snowden and Boone [12], the model of the five disciplines by Senge [10] and the model of the seven dimensions of knowledge management by Terra [13], having as its entrance variable the indicators of refinement of knowledge management from the criteria for Management Excellence by FNQ [3], the Brazilian Quality National Foundation, This model is presented in Figure 1.

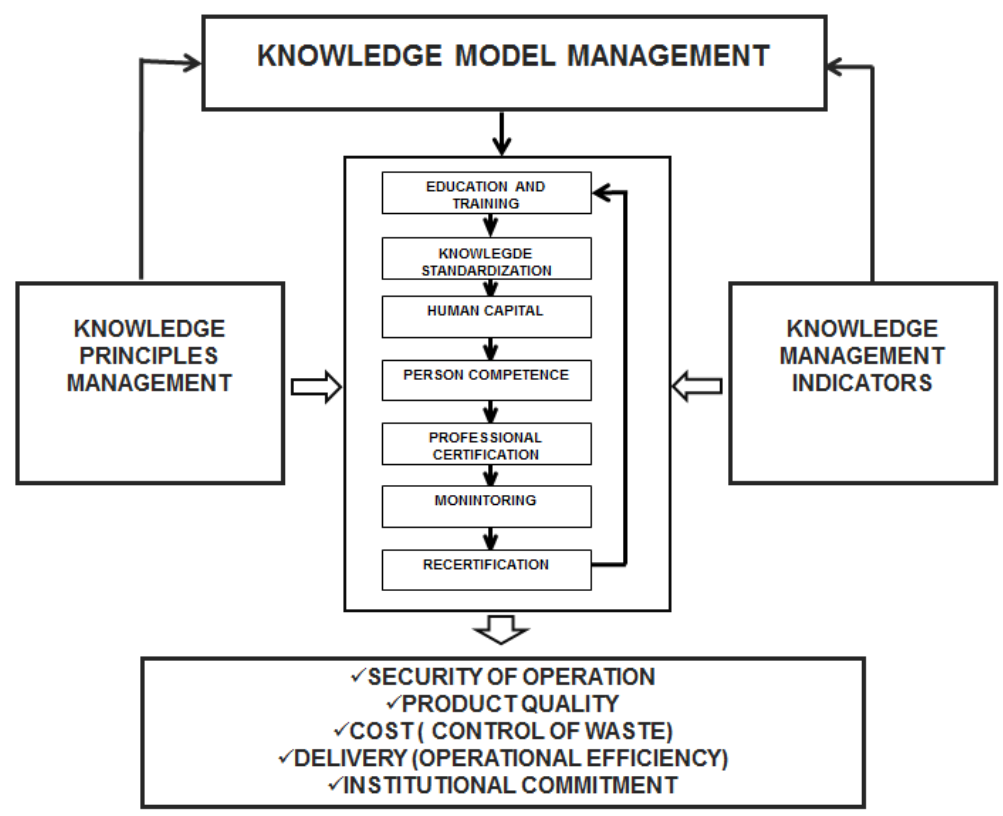

Fig. 1. Skills development model [14] 


\section{Discussion and Results}

The search results are shown in Figure 2.

\begin{tabular}{|c|c|c|c|c|c|c|}
\hline \multirow{2}{*}{ QUESTION } & \multirow{2}{*}{$\begin{array}{l}\text { Value } \\
\text { Medium }\end{array}$} & \begin{tabular}{|c|} 
I agree \\
completely \\
\end{tabular} & I agree & $\begin{array}{c}\text { I partially } \\
\text { agree }\end{array}$ & $\begin{array}{c}\text { I partially } \\
\text { disagree }\end{array}$ & I disagree \\
\hline & & (5) & (4) & (3) & (2) & (1) \\
\hline $\begin{array}{l}\text { 1. The recognized problem of lack of skilled labor in the steel industry } \\
\text { can be properly resolved in the next } 3-5 \text { years? }\end{array}$ & 2,62 & & & & & \\
\hline $\begin{array}{l}\text { 2. There are conditions in Brazil to provide adequate training of } \\
\text { manpower for the steel industry in the long term? }\end{array}$ & 3,50 & & & & & \\
\hline $\begin{array}{l}\text { 3. The low educational qualification of the labor market is offering is one } \\
\text { of the obstacles to adequate professional training of operators of the } \\
\text { steel industry? }\end{array}$ & 4,0 & & & & & \\
\hline $\begin{array}{l}\text { 4. The company clearly recognizes that the way to improved results and } \\
\text { it is through a program of education and training? }\end{array}$ & 4,37 & d & & $\Delta^{-}$ & & \\
\hline $\begin{array}{l}\text { 5. The company is concerned substantially standardize the knowledge } \\
\text { that is at the head of its employees and describe it in operational } \\
\text { procedures? }\end{array}$ & 4,25 & o & & $\Delta$ & & \\
\hline $\begin{array}{l}\text { 6. The company recognizes the importance of strengthening its human } \\
\text { capital to produce improvements? }\end{array}$ & 4,25 & d & & 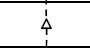 & & \\
\hline $\begin{array}{l}\text { 7. Training people is associated with the strategic needs of the } \\
\text { company? }\end{array}$ & 4,62 & & & $\Delta$ & & \\
\hline $\begin{array}{l}\text { 8. The company recognizes that one way of solving functional illiteracy is } \\
\text { through training and professional certification? }\end{array}$ & 4,0 & d & & $\Delta$ & & \\
\hline $\begin{array}{l}\text { 9. One of the ways that an organization has to reduce operating costs is } \\
\text { the participation of people in solving problems and this is only possible } \\
\text { by changing your mindset? }\end{array}$ & 4,37 & d & & $\dot{\Delta}$ & & \\
\hline $\begin{array}{l}\text { 10. Reducing the number of accidents in a steel plant is directly related } \\
\text { to a robust program of education and training? }\end{array}$ & 4,37 & d & & 4 & & \\
\hline $\begin{array}{l}\text { 11. People no longer only supplier of manpower to be achieved the rank } \\
\text { of suppliers of knowledge and skills? }\end{array}$ & 4,25 & $\phi$ & & $\stackrel{\Delta}{i}$ & & \\
\hline $\begin{array}{l}\text { 12. It is through a certification program for people who are adequately } \\
\text { assess the level of competence of its employees? }\end{array}$ & 4,0 & 1 & & $\Delta$ & & \\
\hline $\begin{array}{l}\text { 13. The strengthening of human capital contributes to better decision } \\
\text { making in their area of expertise? }\end{array}$ & 5,0 & & & & & \\
\hline $\begin{array}{l}\text { 14. The strengthening of human capital contributes to better decision } \\
\text { making in their area of expertise? }\end{array}$ & 4,87 & & & & & \\
\hline
\end{tabular}

Fig. 2. The average values profile [14]

In the short term average of the opinions of representative governance of the national steel industry was 2.62 for question 1 and long-term improvement in the perception through actions aimed at reducing the educational gap, tending to a value of 4.0 based on Likert scale. From the behavior of the average value ranging from 4.0 to 5.0 obtained from the point 5 to the point 14 , there is a strong correlation with respect to the model.

To provide an analysis of the results, it was structured a correlation matrix among the indicators of each issue, which aims to understand the relationships and interactions, which are set out in Figure 3.

We identified three discrepancies between the respondents, namely: the first is that there is agreement on the standardization of knowledge, but it is not a consensus due to different organizational cultures; the second is that the reduction of accidents in a steel plant is obtained with a solid Education and Training program, emphasized by one group, and another group also adds the responsibility of leadership and governance; third, it is recognized that professional certification is the way to address the functional illiteracy, but in practice what we see is only the assistance to the legal requirements. 


\begin{tabular}{|c|c|c|c|c|c|c|c|c|c|c|c|c|c|c|c|}
\hline QUESTION & $\underbrace{\text { QUESTION }}_{\text {INDICATOR }}$ & 1 & 2 & 3 & 4 & 5 & 6 & 7 & 8 & 9 & 10 & 11 & 12 & 13 & 14 \\
\hline 1 & LABOR & & & & & & 0 & & & & & 0 & & & \\
\hline 2 & \begin{tabular}{|l|} 
ESPECIFIC \\
KNOWLEDGE
\end{tabular} & & & & & & & & 0 & & 0 & & & & \\
\hline 3 & LOW KNOWLEDGE & & & & 0 & O & & & & & & & & & \\
\hline 4 & TRAINING & & & & & & 0 & & & & 0 & & & & \\
\hline 5 & STANDARDIZATION & & & & & & & & & 0 & & & & & 0 \\
\hline 6 & HUMAN CAPITAL & & & & & & & & & 0 & & & & 0 & \\
\hline 7 & STRATEGIES & & & & & & & & O & & & & & & O \\
\hline 8 & $\begin{array}{l}\text { FUNCTIONALLY } \\
\text { ILLITERATE }\end{array}$ & & & & 0 & & & & & & & & 0 & & \\
\hline 9 & COST REDUCTION & & & & & & & & & & & 0 & & 0 & \\
\hline 10 & \begin{tabular}{|l|} 
ACIDENT \\
PREVENTION \\
\end{tabular} & & & & & & & & & & & & 0 & & 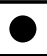 \\
\hline 11 & \begin{tabular}{|l} 
SUPPLIER \\
\end{tabular} & 0 & & & & & & & & & & & & & O \\
\hline 12 & COMPETENCE & & 0 & & & & & & & & & & & & 0 \\
\hline 13 & DECISION MAKING & & & & 0 & & & 0 & & & & & & & \\
\hline 14 & CERTIFICATION & & & & 0 & & & & & & & & & & \\
\hline
\end{tabular}

Fig. 3. Correlation between indicators [14]

It was noted that the process approach allows a systemic and a better understanding of the proposed objectives, coupled with the fact that all interviewees were unanimous in asserting that the strengthening of human capital improves the decision-making, and the creation of Corporate Universities by the steel companies is the way to reduce the gap in educational sector.

\section{Conclusions}

The concern of governance is real and imminent in face of the difficulties of acquiring new professionals and the rate of retirement of the current workforce. One cannot fail to mention fierce competition from imported products.

The productive capacity of the Brazilian steel industry for 2015 is estimated at 50 million tons of steel to meet the new planned projects, such as the World Cup 2014, the 2016 Olympic Games and the extraction of oil in deepwater pre-salt.

The model of skills development proposed for the mining-metallurgical sector was ratified by the representative governance of the sector, accounting for $76.2 \%$ of steel production in Brazil in 2010, represented by companies ArcelorMittal, Gerdau, Usiminas and Votorantim. 


\section{References}

1. Arruda, M.: Qualificação versus Certificação. Boletim Citerfor no (Maio/Agosto de 2000)

2. ABNT, ABNT NBR 9000:2005-Vocabulário e Princípios. ABNT, Rio de Janeiro (2005)

3. FNQ: Critério de Excelência. Fundação Nacional da Qualidade (2010)

4. Nonaka, I., Takeuchi, H.: Criação do conhecimento na empresa. Campus, São Paulo (1997)

5. Campos, V.F.: Controle da Qualidade Total. Block Editores, São Paulo (1992)

6. Ishikawa, K.: What is Total Quality Contol? The Japanese Way. Prentice-Hall (1985)

7. Feingenbaum, A.V.: Total Quality Control-3º Edição. McGraw Hill Company (1986)

8. Deming, W.E.: Qualidade: A Revolução da Administração. Marques Saraiva, São Paulo (1990)

9. Juran, J.: Planejamento da Qualidade. Livraria Pioneira (1990)

10. Senge, P.M.: A Quinta Disciplina. Best Seller (2009)

11. Davemport, T.H., Prusak, L.: Conhecimento Empresarial. Campus, Rio de Janeiro (1999)

12. Snowden, D.: Complex acts of knowing-paradox and descriptive self-awareness (2002)

13. Terra, J.C.C.: Gestão do Conhecimento: O grande desafio empresarial (2005)

14. Moreira Filho, U.M.: A excelência no controle do processo produtivo com foco no conhecimento e qualidade: Estudo de caso da siderurgia brasileira. UNIP. UNIP, São Paulo (2012) 